\title{
CHUVASH EDUCATOR I. YA. YAKOVLEV AND THE BASICS OF THE ETHNIC JOURNALISM SCHOOL
}

\author{
Anatoliy P. Danilov ${ }^{1}$, Andrey A. Danilov ${ }^{\star}{ }^{\star}$, Lyudmila A. Vasilyeva ${ }^{3}$, \\ Oleg R. Studentsov ${ }^{4}$, Galina V. Khoraskina ${ }^{5}$ \\ ${ }^{1}$ Head of Chair, Chuvash State University, RUSSIA, anatoliy.p.danilov@gmail.com \\ ${ }^{2}$ Prof. Dr., Chuvash State University, RUSSIA, danilov.andrey@mail.ru \\ ${ }^{3}$ Assoc. Prof., Chuvash State University, RUSSIA, milavas71@mail.ru \\ ${ }^{4}$ Assoc. Prof., Chuvash State University, RUSSIA, studor2@yandex.ru \\ ${ }^{5}$ Assoc. Prof., Chuvash State University, RUSSIA, ahmer_hor@mail.ru \\ ${ }^{*}$ Corresponding Author
}

\begin{abstract}
The purpose of the study is to analyze the peculiarities of reflection oa the spiritual and moral foundations of the Chuvash people in I.Y. Yakovlev's publications and the activities of his school of ethnic journalism on a systematic level. It is noted that the literature about I. Ya. Yakovlev, both scientific and fiction, is extensive, but not all aspects of the multifaceted activities of the patriarch of the Chuvash culture have been fully investigated. Special attention is paid to the active publishing and translation activities of I.Ya. Yakovlev. The work analyzes the activities of the Simbirsk Chuvash school. The authors analyzed the activity of Simbirsk Chuvash school graduates who later worked in the editorial offices of newspapers and magazines. The authors conclude that the traditions of the Yakovlev's school in the Chuvash journalism have been preserved until now. I.Ya. Yakovlev's pedagogical and creative heritage has a great influence on the development of all aspects of the spiritual culture of the Chuvash people, in particular, on the formation of professional journalism. The activity of the branch of the Journalism Department at the Union of Journalists of Chuvashia, the work of students in creative studios under the guidance of the leading representatives of radio channels and TV studios, chief editors of the republic' printing editions is noted. The work of the small division of journalism, created for the purpose of organizing career guidance work, management bodies of the journalism division, student scientific society, editorial and publishing center has been studied; the level of material and technical base of the division has been assessed.
\end{abstract}

Keywords: I.Ya. Yakovlev, ethnic journalism, mass media, Chuvashia, history, culture

\section{INTRODUCTION}

Publishing and journalistic activities take a significant place in the huge creative heritage of the patriarch of the Chuvash people I.Ya. Yakovlev. The relevance of the research topic is determined by the fact that the Simbirsk Chuvash School created by I.Ya. Yakovlev has brought a large galaxy of talented journalists and undoubtedly influenced the development of journalism in the modern conditions. Opened in 1868, the school for Chuvash children, transformed in October 1917 into the Simbirsk Chuvash Teachers' Seminary, from September 1, 1920 to the Chuvash Institute of Public Education, then to the Chuvash Pedagogical School, this institution has been a factory of not only teachers for 88 years. Many of its graduates successfully worked in the periodical press later. The great publishing and journalistic experience of the teacher I.Ya. 
Yakovlev helped them in their professional activities. The purpose of the study is to analyze the peculiarities of the reflection of spiritual and moral basics of the Chuvash people in I.Y. Yakovlev's journalism and activities of his school of ethnic journalism at a systemic level.

\section{METHODOLOGY}

The methodological basis of this study includes the principles of historicism, consistency and holistic research, which made it possible to analyze the general regularities of historical and cultural processes. The peculiarities of the formation of ethnic journalism in Chuvashia; its relationship with social and political and cultural changes in the society were considered on the basis of historical and typological method. The work used an interdisciplinary approach at the intersection of historical science and journalism.

\section{RESULTS}

The literature about I. Ya. Yakovlev, both scientific and fiction, is extensive, but we cannot state that all aspects of the multifaceted activities of the patriarch of the Chuvash culture have been fully investigated. Even the pretender for completeness "Index of books, brochures, articles, and notes about the Chuvash people in Russian", compiled by priest A. Ivanov in 1907 indicates only the following publications of I.Ya. Yakovlev: 1. "Concerning the note by S.Ya on Zemstvo foreign schools" (Simbirsk Province Journal, 1894. No. 26); 2. "Archpriest Alexei Ivanovich Baratynsky" (Ibid. No. 47); 3. "On school education of the Chuvash" (City and village teacher. 1897); 4. "The Chuvash Pedagogical College in Simbirsk and the Women's School at it" (Orthodox blessed messenger 1893. No. 11); 5. "Considerations about the spread of female education between the Chuvash" (Ibid. No, 1) 6. "Simbirska Chuvash Pedagogical College and the Women's School at it" (Church News, 1893. No. 24); 7. "Report on the temporary teacher training courses organized at the Simbirsk Chuvash Pedagogical College in 1891 for teachers of Chuvash primary schools" (Simbirsk, 1899); 8. "Article by I. Yakovlev against the use of the Chuvash language in schools" (Simbirsk Province Journal, 1868). The authorship of the latter publication is questionable..

This list does not include, for example, I.Ya. Yakovlev's first experience in the newspaper - a historical and ethnographic essay "The Chuvash Holiday of Uchuk" (Simbirsk Province Journal. 1867, March 28 - April 4). This publication is not only of scientific importance, but is also interesting for a wide range of readers. The author showed a profound knowledge of folk traditions and customs and acted as a passionate supporter of public and cultural interests of his people.

A wide range of interests of I.Ya. Yakovlev became apparent in another material published in the same edition. It was a review of the first Chuvash calendar drafted by N.I. Zolotnitsky. The author's critical approach is expressed in the lines that point to the calendar's shortcomings; in particular, it draws attention to the fact that N.I. Zolotnitsky does not take into account the originality of the reader, their national features. Here, I. Ya. Yakovlev writes about the need to create the Chuvash alphabet for the first time.

The whole life of I.Ya. Yakovlev was a struggle. In the conditions of continuous slander, as a "politically unreliable" person, he has trials with slanderers; polemizes with opponents from the pages of the press. Therefore, his publications in the press are characterized primarily by polemicism. He starts any big case by discussing it in the press. It was so at creation of the Chuvash alphabet, at opening of Simbirsk Chuvash school and the network of rural schools for the population.

I. Ya. Yakovlev has always been active in publishing and translation activities. In 1896, he published the book "The First Universal Population Census of the Russian Empire" in Chuvash language, translated by himself. A little later, the books "A Brief Essay on the Development of the Simbirsk Chuvash Pedagogical College" (1908); "Report on the State of the Agricultural Farm of the Simbirsk Chuvash Pedagogical College in 1912" (1913); "The War and the Chuvash School in Simbirsk" (1915) were published. Books by I. Ya. Yakovlev on raising the level of peasant agriculture "Report on the state of the agricultural farm of the Simbirsk Society transferred to the Simbirsk Chuvash Pedagogical College, from March 15, 1893 to January 1894" (1895); "Brief essay of Simbirsk Chuvash Pedagogical College" (1908); "Report on the state of the agricultural farm at Simbirsk Chuvash Pedagogical College in 1912"(1913); "Reference of inspector of Chuvash schools of Kazan educational district to Buinsky territorial department dated October 3, 1899", and others. Of course, the most significant phenomenon in I.Ya. Yakovlev's publishing activity was the publication of the "ABC-book for Chuvash" (33 editions during the author's lifetime.

I.Ya. Yakovlev formulated the principles of mutual relations between the two peoples in the following way: "The Russian people have suffered their truth, and there is no doubt that they will share this truth with you. Believe in Russia, love it, and it will be a mother to you. This principle is fully reflected in his journalistic and literature works. 
I.Ya. Yakovlev has always been active in publishing and translation. In 1896, he published the Chuvash translation of "The First Universal Population Census of the Russian Empire" ("Пирӗн Вырӑc Патшалӑхӗнче пурӑнакан с̧ынсене пурне те с̧ырса тухасси с̧инчен"). A little later, the books "A Brief Essay on the Development of the Simbirsk Chuvash Pedagogical College " (1908); "Report on the State of the Agricultural Farm of the Simbirsk Chuvash Pedagogical College in 1912" (1913); "The War and the Chuvash School in Simbirsk" (1915) were published. The books by I. Ya. Yakovlev on raising the level of peasant farming: "Report on the state of the agricultural farm of the Simbirsk Society transferred to the Simbirsk Chuvash Pedagogical College, from March 15, 1893 to January 1894". (1895); "Brief essay of Simbirsk Chuvash Pedagogical College" (1908); "Report on the state of the agricultural farm at Simbirsk Chuvash Pedagogical College for 1912" (1913); "Reference of inspector of Chuvash schools of Kazan educational district to Buinsky territorial department dated October 3, 1899", and others. Of course, the most significant phenomenon in I.Ya. Yakovlev's publishing activity was the publication of the "ABC-book for Chuvash" (33 editions during the author's lifetim (Dimitriev, Leontiev Matveev, 2011, p. 125)).

Thus, as the famous researcher of the creative heritage of I.Ya. Yakovleva I.Ya. Tenyushev emphasizes, the literary and journalistic activity of the patriarch can be divided into 4 periods: 1 . The initial period (18671875); 2. The period of development of the program of national revival of the Chuvash (1875-1893); 3 . The work of the national educator in the years of increasing persecution of the Chuvash schools (1894-1917); 4. Literature activity in 1917-1922 (Danilov, 2017, p. 71).

In the last years of his life, I.Ya. Yakovlev wrote mainly works of memoir character, among which "My Life" memories took a significant place..

Even during I.Ya. Yakovlev's lifetime, famous Chuvash literary figures Konstantin Ivanov, Taer Timkki, S.S. Semyonov (Sorokin), Vassya Anissi, Metri Yuman, Nikolai Shubosinni, Maria Ukhsay, Vasily Mitta, Fyodor Pavlov and others, whose works were first published in the periodical press studied at the Simbirsk Chuvash school.

Simbirsk Chuvash School had different names at different times: school, seminary, technical school, and college. Until its closing (1956), it had the status of the Ulyanovsk Chuvash Pedagogical College. No matter how the names were changed, the school always tried to preserve the traditions of I. Ya.Yakovlev. Students were proud of his name; the good spirit of the patriarch was always present in the school. Even the incomplete list of graduates of the Simbirsk Chuvash School, who later worked in the editorial offices of newspapers and magazines, shows how strong the influence of this educational institution on the development of spiritual culture of the people was. The graduates and staff of the Simbirsk Chuvash school include well-known journalists (Leontiev, 2012, p. 37).

Pavel Mironov (1861-1921) graduated from the Simbirsk Chuvash School in 1879. In 1908-1909 he published a monthly magazine, which published articles on pedagogical, historical, ethnographic topics.

Petrov Dmitry Petrovich (Metri Yuman) (1885-1939). In 1899-1905, he was a student of the Simbirsk Chuvash school. In 1906-1907, he worked in the newspaper "Simbirsk News" and in the Kazan newspaper "Volzhsky News"; in 1913 in the editorial office of "Kazanskaya Newspaper"; in 1918-1921 - in the republican newspaper "Kanash"; in 1933-1934 - correspondent for the Chuvash newspaper "Kommunar."

Timofey Semenov (Taer Timkki) (1889-1916) graduated from the Simbirsk Chuvash School in 1916. Artist, photographer. Illustrated the Chuvash magazine "Ana" ("Niva").

Repin Kuzma Vasilyevich (1897-1923) in 1912-1917 was a student of the Simbirsk Chuvash school. His works were published in the newspapers "Khypar" and "New Life" (Matrosov, Leontiev, 2006, p. 5).

Anisya Vasilievna Vasilyeva-Knyaginina (Vassya Anissi) (1893-1975) studied at the Simbirsk Chuvash School in 1905-1906. Her works were published in the newspaper "Khypar."

Kiryushkina (Razubayeva) Evdokia Stepanovna (born 1919), in 1934-1937 - a student of the Chuvash pedagogical school; in 1940-1942. - correspondent of the Bogdashkinsk newspaper "Kolkhoznaya Pravda"; in 1942-1945, executive secretary of the Sengileevskaya newspaper "Stalin Organizer".

Ukhsay Yakov Gavrilovich (1911-1986) worked at the Ulyanovsk Chuvash Pedagogical College from 1937 to 1939. From 1930 to 1933, he was a member of the editorial staff of the Chuvash newspaper "Kommunar" which was published in Moscow. He was the national poet of Chuvashia.

From 1938 to 1941, Petrov Konstantin Konstantinovich studied at the Ulyanovsk Pedagogical College, worked for a long time in the Chuvash language editions of Tatarstan; taught journalism at Kazan and Chuvash State Universities. He was an associate professor at the Faculty of Journalism at Chuvash State University. 
Milyudin Ilya Nikolaevich (born 1923) was a student of the Chuvash pedagogical school in 1937-1940; in 1942-1947 - editor of the Bogdashkinskiy district Chuvash newspaper "Collective Labour"; in 1955-1962 the first deputy editor of the regional newspaper "Ulyanovsk Truth."

Obdirkin Gerasim Emelianovich (1900-1985) was a student of the Chuvash pedagogical school in 19221926; from 1927 to 1929 - director of the seven-year school at the Ulyanovsk Pedagogical College; from 1919 to 1921 - a literature worker of the Chuvash newspaper "New Life."

Kiryushkin Ivan Sergeyevich (1919-1996) studied at the pedagogical school in 1934-1937; in 1951-1952 executive secretary of the Bogdashkinsk newspaper "Collective Labour"; in 1952-1958 - executive editor of the Melekessk newspaper "Stalin Flag"; in 1959-1961 - executive secretary of the newspaper "State Farm Truth" of the Krupskaya Melekessk district farm; in 1961-1965 - director of the Melekess city printing house; 1965-1966 - editor of the Novomalyklinsk newspaper "Star"; 1987-1995 - chairman of the Ulyanovsk Chuvash Cultural and Educational Society named after I.Ya. Yakovlev.

Romanov Alexey llyich (born 1927) in 1940-1941, 1943-1944 was a student of the Chuvash pedagogical school; in 1961-1962 - editor of the Bogdashkinsk Chuvash newspaper "Collective Labour"; 1962-1963 deputy editor of the Ulyanovsk inter-district newspaper "Motherland of Ilyich"; in 1966-1986 - editor of the Tsilninsk district newspaper "Dawn of Communism."

Bogatov Alexander Mikhailovich (born 1935), in 1950-1954 - student at the Chuvash pedagogical school; 1984-1985 - deputy editor of the newspaper "Ulyanovsk Truth"; in 1985-1989 - head of the Press Sector of the CPSU Regional Committee; 1992-1993 - correspondent of the Ulyanovsk regional Chuvash newspaper "Kanash"; since 1995 - own correspondent of the newspaper "Kanash."

Tukhtamanov Vladimir Sevostianinov (born 1935) was a student of the Chuvash pedagogical school in 1950-1954; in 1980-1988 - editor of the Staromaisk District newspaper "Lenin spark"; since 1988 - the deputy editor of the newspaper "Lenin spark".

Gordeev Alexander Petrovich (born 1938) was a student of the Chuvash pedagogical school in 1953-1956; in 1962-1974 - employee of the republican Komsomol newspaper (Cheboksary).

\section{CONCLUSION}

Thus, the researchers have yet to compile a full list of graduates of the Simbirsk Chuvash School who have proven themselves on the journalistic path. However, we can already assert that traditions of the Yakovlev's school in the Chuvash journalism continue to exist today. The materials discussed above allow us to conclude that the pedagogical and creative heritage of I.Ya. Yakovlev has a great influence on the development of all aspects of the spiritual culture of the Chuvash people, in particular, on the formation of professional journalism. The Yakovlev's School of Journalism helped to establish and develop the modern mass media system both in the Chuvash Republic and in the Diaspora. This is extremely important taking into account the fact that about half of the Chuvash population lives outside of the Chuvash Republic. We have to raise the ideas of the Chuvash culture patriarch to a new level under new conditions; the task of implementing them has become the need of every patriot of his nation.

\section{ACKNOWLEDGEMENT}

The reported study was funded by RFBR and Chuvash Republic according to the research project № 19412-210003.

\section{REFERENCE LIST}

1. Danilov, A. P. and Danilov, A. A. (2017). History of formation and development of journalistic education at the Chuvash state University named After I. N. Ulyanov. Bulletin of the Chuvash University, 2.

2. Dimitriev, V. D., Leontiev, A. P., Matveev, G. B. (2011). N. V. Nikolsky - scientist, educator, public figure.

3. Leontiev, A. P. (2012). N. V. Nikolsky - the founder of the Chuvash-language media. Bulletin of the Chuvash University, 1.

4. Matrosov, I. M. and Leontiev, A. P. (2006). The first Chuvash newspaper "Khypar" 1906-2006. 